\title{
Stephen Leacock and the Macmillan Company of Canada
}

\author{
Carl Spadoni
}

'TO MY GREAT REGRET GUNDY AND I FAIL TO AGREE ON TERMS. HENCE THE Canadian rights and sale of WINNOWED WISDOM will be taken over by the Macmillans. ' ${ }^{\text {I }}$ Those words were written by Stephen Leacock on 6 February 1926 in similar letters addressed to his American publisher, Dodd, Mead \& Co., and his English publisher, John Lane The Bodley Head. It marked the end of Leacock's business relationship with the Canadian firm, S.B. Gundy, which had published Sunshine Sketches of a Little Town in I9 2 and more than a dozen other books written by Leacock in the intervening years. He assured his American and English publishers that he wanted to maintain their services for as long as he was able to write books and that the Macmillan house in Canada would not control the sale or distribution of his present or future books in their respective countries. On the same day the terms of this agreement were sent by Leacock to Hugh S. Eayrs, the president of the Macmillan Company of Canada. A few days later, Eayrs replied that he was delighted that his firm would be handling Leacock's works in Canada. ${ }^{2}$ Their exchange of letters was in the nature of a contract containing five clauses: (I) the Canadian branch of the Macmillans would own the Canadian rights in Winnowed Wisdom and in Leacock's next two books of humour; (2) the Company would pay a royalty of thirty cents a copy on all copies sold; (3) on the date of publication, Leacock would receive an advance royalty of $\$ 500$ per title; $(4)$ the retail price of each book would be set by the Macmillans; and (5) sheets would be imported from Leacock's New York or London publishers or else manufactured according to Macmillan specifications.

Although the relationship between Leacock and the Macmillan Company formally began in 1926 with the agreement of publication of Winnowed Wisdom, there was a false start in I908. In that year, with two scholarly books and several articles behind him, Leacock was appointed William Dow Professor of Political Economy at McGill University and at the same time became Chairman of the Department of Economics and Political Science. His first book, Elements of Political Science (I906), was a bestseller when it was adopted as a standard textbook for university courses. It would 
appear that Leacock approached Frank Wise, then president of the Torontobased branch, with the idea of writing a book on the Canadian tariff question. Wise was quite receptive to Leacock's proposal but was wary enough to consult his American and English counterparts before proceeding with a contract. Both George P. Brett, the president of the American branch, and Sir Frederick Macmillan, the president of the English branch, reacted negatively. The maximum number of copies that each expected to sell was less than one hundred. In short, their past experience indicated that a book on such a restricted theme had a potentially small market and therefore was likely to be an unprofitable venture. Leacock naturally must have been upset when Wise reversed his decision about publication. 'I thank you for offering to take Ioo copies of Professor Leacock's proposed book,' Wise wrote to Sir Frederick. 'After going into it thoroughly however from a possible sales standpoint, I have decided that there is not at present a sufficient demand to warrant our taking the risk. I have therefore wiped it off our slate. ${ }^{3}$

In retrospect, Wise's cautious decision was short-sighted. It was probably too late to make amends with Leacock once John Lane had the prescience to publish Leacock's first book of humour, Literary Lapses, in I9 Io and had engaged S.B. Gundy to take care of Canadian sales. It is perhaps ironical that Gundy, which also represented Oxford University Press in Canada, shared quarters with the Canadian branch of the Macmillans at 25-27 Richmond Street West in Toronto before the latter moved to St. Martin's House at 70 Bond Street in June I9ro. Unfortunately, two years later, Wise compounded his earlier mistake. Having acquired the rights to the series, Chronicles of Canada for Boys and Girls, published by Morang, to which Leacock had contracted to contribute, Wise promptly sold the entire rights in the series to Glasgow, Brook \& Co. ${ }^{4}$ Thereafter, without success, Wise was looking for ways to tempt Leacock back to the Macmillan Company. As late as I 920, for example, he informed Brett that Leacock's contract with Lane was about to expire:

If properly nursed Leacock will not renew with Lane since there seems to be a certain perennial delay in getting royalty statements and cheques, and Leacock is fed up with Lane's agent here, Gundy.... Leacock was under a long term contract with Lane and therefore I should think his royalty was not a heavy one. I understand he is doing a little fishing around amongst the publishers. I have managed to get word in to him.... ${ }^{5}$

In contrast with the false state of I908, the situtation had changed enormously by the middle of the I920s. The professor from McGill had become a Canadian celebrity, a world-famous humorist, an engaging speaker, and a prolific author. Despite the fact that Leacock continued to produce a book of humour almost on a yearly basis, his most successful period as a 
humorist unfortunately was over. Nonetheless his annual income from royalties exceeded $\$ 20,000 .{ }^{6} \mathrm{He}$ could indulge in writing scholarly material or social polemic without the prospect of lucrative results.

For the Canadian branch of the Macmillans, the times were also different. Gone were the uncertain years when the house acted primarily as a distributor of Macmillan titles published in New York and London. Wise had departed in I92I, and at the age of twenty-six, Eayrs was appointed in his place. Urbane and ambitious but sometimes arrogant and impulsive, Eayrs led the Company for the next two decades in promoting the cause of Canadian literature, attracting such authors as Mazo de la Roche, Grey Owl, Morley Callaghan, Frederic Philip Grove, and E.J. Pratt. A high-profile member of the Canadian Authors Association and the former editor of several prominent trade journals, Eayrs believed that Canada was experiencing a literary renaissance. ${ }^{7} \mathrm{He}$ understood that publishing is more than the printing and distribution of books and that authors have to be catered to individually: 'You know the very real affection I have for you,' he told Leacock in a letter beginning 'My dear Stephen.' 'We're a bit different I feel from the average publisher and author: we are that but we're pals as well.... ${ }^{8}$ In spite of certain instances of doubt which he expressed about Eayrs's ability, Leacock warmly reciprocated Eayrs's friendship. Their correspondence is cordial, direct, and honest, without any attempts to cheat each other or to get the upper hand. More important than the letters which they exchanged were Eayrs's many personal visits to Leacock at Montreal and Orillia. Yet, at least from Eayrs's point of view, their business relationship was not particularly satisfactory. Eayrs's aspiration was that the public would recognize his firm as representing Leacock in Canada; not only would the Macmillan Company publish all of Leacock's forthcoming books but the older popular titles would eventually be reissued under the Macmillan imprint. As natural as this aspiration might have been, it was not to be fulfilled. Perhaps what is interesting about their interaction is the extent to which a publisher will try to accommodate an author in the hope that both will flourish thereby.

Besides Winnowed Wisdom (I926), the two other books of humour that Leacock published with the Macmillan Company of Canada in accordance with the first clause of his contract were Short Circuits (1928) and The Iron Man e) the Tin Woman (1929). 'The poorest single book of humour he ever wrote' is the judgement of Leacock's biographer, Ralph L. Curry, on Short Circuits, and although he regards the other two books not quite as harshly, he considers their humour strained, attributing the failure in all three to haste in writing and to the death of Leacock's wife in December $1925 .{ }^{9}$ In fact, for all three books, the reviews were mixed. The role that the Macmillan Company played in their publication appears to have been secondary 
since sheets for the Canadian edition of The Iron Man et the Tin Woman were obtained from Dodd, Mead \& Co. and from John Lane The Bodley Head in the case of the other two books. Disappointingly, very little publishing information concerning these Canadian editions is available from the Leacock-Macmillan correspondence. The Canadian edition of The Iron Man $\Theta$ the Tin Woman was published on 25 November 1929, and at the end of March I930, 796 copies had been sold. In the second year of the publication of Short Circuits, only 90 copies of the Canadian edition were sold. ${ }^{\text {Io }}$ This meager information suggests that these books were hardly moneymakers for the Macmillan house. This fact is confirmed in a letter Eayrs later wrote to Leacock: 'As you know we always took care of the books of humour by paying outright for them whether they earned their way or not (and I am frank to say that in several cases they didn't $t$..... ${ }^{\text {II }}$

Following the death of his wife, Leacock channelled his energies into his academic work. An indication of his redirected vigour was his involvement in the publication of theses written by his graduate students. Once Gundy was displaced as his Canadian publisher, Leacock enlisted the Macmillan Company's cooperation in this endeavour. Indeed, the extant correspondence between 1926 and 1929 is chiefly on this subject and reveals that had it not been for Leacock's determination and influence, the theses would never have been published.

On 26 April I926, Leacock drafted an agreement for a proposed monographic series, the McGill University Economic Studies on the National Problems of Canada (Series xv). ${ }^{12}$ For the opportunity of owning the rights to this series, the Macmillan Company was responsible for arranging and paying for the printing, binding, circulation, and sale of each thesis. McGill originally paid the Macmillans fifty dollars for each thesis published in return for which the university received 50 free copies of each monograph. There were to be no royalties given to the authors unless sales of a monograph exceeded 500 copies in which case a Io percent royalty applied. But these clauses were hardly compensatory factors for the Macmillan Company, and clearly the series was a losing proposition from the outset. The first four studies which sold for forty cents apiece were bound in red paper wrappers with gatherings stapled together. When W.W. Goforth, a fellow professor in the Department of Economics and Political Science, wanted to raise the retail price to one dollar for each of the next four monographs to be bound in cloth, Eayrs advised Leacock that such a price hike was drastic and that the Macmillan Company would lose even more money on the series:

I suppose Goforth has considered this matter pretty well, but, for my own part, I think he is wrong. Consider what has happened so far: you have been moderately successful with a series of Monographs retailing at 40 cents. Such copies as we sold for you, and 
we did fairly well under the circumstances, were sold to the trade at $25 \%$ off that 40 cents - in other words, we gave the trade a $25 \%$ discount. The only spread we got ourselves was 4 cents for we bought from you at 25 cents. That 4 cents doesn't even pay our overhead, and I do not care whether it does or not. The idea of the Monographs appealed to me because they were sound stuff, and I was willing to take an underprofit for the sake of the association with your Department.... I am still willing to take virtually no profit on the new books. All this preamble by way of letting you know that I don't care a rap whether there is any money in it for us or not. Ilike the idea, and I want to continue an association with you and your Department to the development of the idea. ${ }^{\text {I3 }}$

In the end a compromise was reached, and numbers 4 to 8 of the series sold for seventy-five cents each and were bound in stiff paper; numbers 9 to I 3 which retailed for one dollar each were bound in red buckram.

Besides negotiating the contract with the Macmillans, Leacock wrote prefaces for six of the seventeen theses which were published. ${ }^{\mathrm{I} 4}$ The first three of his prefaces contain the same paragraph alluding to the present critical era, the situation of our country, the great importance of our national finance and our national problems.' The theses are said to be 'a contribution' to our understanding of these problems 'written from a purely scientific and academic standpoint and without reference to partisan politics and particular interest.' The thesis topics varied from an examination of a Canadian industry to a discussion of a particular aspect of the Canadian economy. Even though the contributors were students at the time, several later distinguished themselves - T.H. Harris, the author of The Crow's Nest Agreement (no. I3), became executive editor of the Montreal Herald, and Eugene Forsey, the author of The Economic and Social Aspects of the Nova Scotia Coal Industry (no. 5), became an important scholar and political scientist, an authority on the Canadian union movement, a member of Parliament, a senator, and an interpreter of constitutional law.

Leacock never referred to himself as the editor of the McGill monographic series. In his prefaces to numbers 2 and 4 , he expresses the department's obligation to Goforth, 'under whose direction and editorship this booklet, and others, have been prepared.' In later correspondence he speaks of the series as edited by the department as a whole. ${ }^{\mathrm{I} 5}$ But his modesty conveys the mistaken impression that he played a minor editorial role. 'You must cut Frisey's [Forsey's] thesis,' he instructed Goforth. 'I will consent that Tombs may have more words provided that he pays the difference any number of charts and maps if he pays for them but not a different form. ${ }^{\text {I6 }}$ When one student complained that his thesis had not yet been published, Leacock replied that since the student did not appreciate the extent of Leacock's efforts, the student was at liberty to publish the thesis 
elsewhere: 'I fear you do not realize how difficult it is to meet the cost of publications of this sort, or how fortunate you are to have people in my position trying to beg money to print what you write. ${ }^{\text {I7 }}$

With respect to the first four monographs, the Macmillan Company purchased 300 copies of each title, but when the price of the next four studies was raised, the Company took 300 copies of each on consignment which were to be sold to the trade at sixty cents, 20 percent discount off the list price of seventy-five cents. Besides being listed in the Macmillan catalogues, the monographs were itemized and described on a separate order form. An interested buyer could check the desired monographs and mail the form to Leacock, care of the Macmillan address. Quite predictably, the series sold very poorly. By April I929 Forsey's thesis had sold 290 copies, the most copies sold of any individual title. Many of the titles sold less than roo copies. ${ }^{18}$ Leacock's involvement is particularly discernible in the publication of the last four monographs published by the Macmillans (nos. 9 to I3), manuscripts of which arrived at the Toronto office in November r 928 but were not published until the end of February 1930. Although he had committed himself to the publication of the McGill series, Eayrs was tentative about any long-range programme of publication. On the one hand, he wanted to maintain his good relationship with Leacock; on the other hand, the Company was going to lose even more money on the series with the inflated price of one dollar for each copy. Leacock sensed Eayrs's reluctance, and almost singlehandedly he tried to promote the series. He wrote to major libraries and university departments in North America, hoping that they would order copies. He had review copies sent to leading academic journals. He approached corporations such as Bell Telephone and Canada Steamship Lines with the offer that they could buy advertising in the monographs at $\$ 25$ a page. ${ }^{19} \mathrm{He}$ arranged for the Macmillan Company to receive an extra \$25 per monograph in addition to the \$50 per monograph called for in the original contract. If this was still not enough, Leacock promised that he would 'be personally responsible for $\$ 200$ of the deficit. ${ }^{20}$

'I do not want you to feel that I am not very grateful to you for your personal guarantee,' Eayrs told Leacock. 'I know your generosity, and I do not feel that you should make your own pocket responsible for the publication of the McGill monographs. ${ }^{\prime 2}$ I By 2 I November 1929 the Macmillan Company had already invested between $\$ 650$ and $\$ 700$ towards the publication of numbers 9 to $I_{3}$ of the series, and a month later, it cost the Company another $\$ 700$ to complete the job in editions of 250 copies each. ${ }^{22}$ Notwithstanding \$ 425 secured from advertising, \$300 from McGill, and \$200 from individual orders and subscriptions, the Macmillan Company lost approximately $\$ 500$ on the four monographs alone. Two years later when Leacock inquired about possible royalties, he was informed that no royalties could 


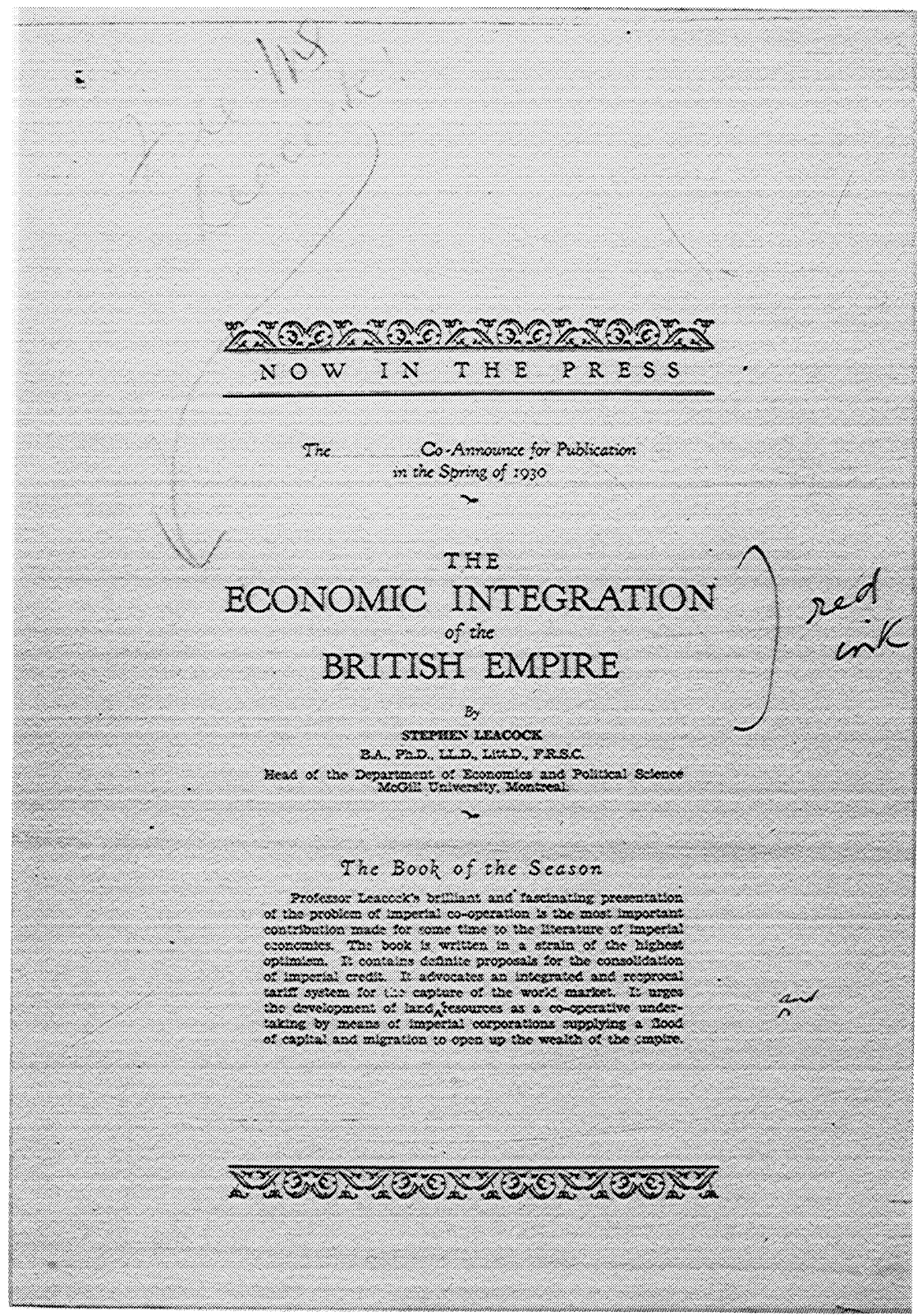

The proof of the first page of Leacock's circular advertising the publication of The Economic Integration of the British Empire in the spring of 1930 . The title of the book was subsequently changed to Economic Prosperity in the British Empire. 
be anticipated since number Io had sold 77 copies; number I I, 2 I 8 ; number I 2, 87; and number I3, $5 \mathrm{r} .{ }^{23}$ It was no doubt due to this substantial financial loss that, shortly thereafter, the Macmillan Company terminated their involvement with the McGill series. Leacock continued to promote the series nonetheless. Numbers 14 to 17 were published at Orillia by the Packet-Times Press in I930. Bound in red wrappers at 75 \& per copy and containing ads similar to those in the previous four monographs, the theses were available at major bookstores in Montreal, Toronto, Winnipeg, and Halifax and were also obtainable by subscription $\$ 2$ a year for four numbers) from Leacock himself. ${ }^{24}$

As we have noted, from I926 to I929 Leacock's relationship with the Macmillan Company was primarily concerned with the McGill Economic Series and secondarily with the publication of Winnowed Wisdom, Short Circuits, and The Iron Man 4 the Tin Woman. Even though he had severed his connection with Gundy and had developed a close friendship with Eayrs, it was not altogether apparent, at least at the beginning of I929, whether Leacock regarded the Macmillans as his sole Canadian publisher. The events that occurred in the next three years settled this question.

In an attempt to get more books published, Leacock decided in November 1929 to 'cut out all lecturing outside McGill and all syndicated humour. ${ }^{25} \mathrm{He}$ had completed the writing of half of a book entitled Chapters in Political Economy but set it aside. ${ }^{26}$ Instead he returned to a subject which pervaded his writings during the first decade of the centuryimperial preference - the advocacy of an integrated and reciprocal tariff system within the British Empire. In 1926 at the Imperial Conference in London, imperial preference was proposed and received Canada's support but England's opposition. Leacock wholeheartedly endorsed the Canadian position. 'I have started and am immensely keen on a new book THE ECONOMIC INTEGRATION OF THE BRITISH EMPIRE,' he enthused to Eayrs. 'I began it some time ago and ... I think we would make a killing.... ${ }^{27}$ In a later related book, Leacock ruefully remarked: 'It was an admirable work but, I fear, only read by the proofreader and, even by him, very hurriedly. ${ }^{28}$ Specifically, he was referring to the left running headlines: the title of the book was changed to Economic Prosperity in the British Empire too late for an alteration in the headlines which employed the earlier title. In general terms, however, Leacock's later remark pointed to the fact that the book did not sell as he had cheerfully predicted. To a great extent, the mediocre showing of Economic Prosperity in the British Empire was the turning point in the losing battle waged by the Macmillan Company to represent Leacock in Canada.

It pleased Leacock immensely when Eayrs telegraphed at once to express 
MCGUL UNIVERSTTY

MONTREAL

Facukry or Amts

Demernixin of teonowica amo

mourrient science

Wear Sayrs

(1) Antiencloned forend it on it com afforve.... obsarre that if we elled we

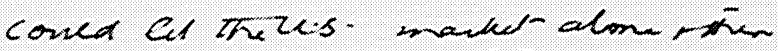

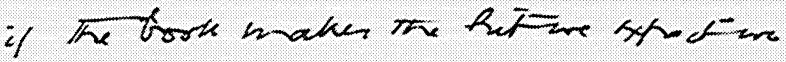
courd pahesos set a teth zate in ine Jiate But y d … accepto 9 wome hed hi Lave it

(2) Hon mans cipies 1 MS necded, 2

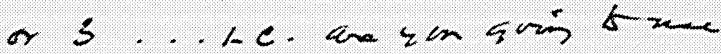

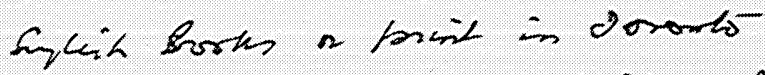

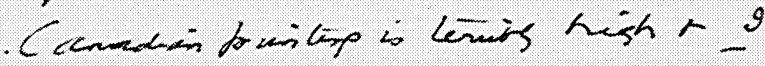
to nut zom under the canadian Cypingl ad becry horn in Enyland

F Circular tin complear rocent les 100 cities dis hishied Rave emo.

$$
\text { Sewarkeacex }
$$

Leacock's letter to Hugh Eayrs, I4 March 1930, in which Leacock discusses the publication and marketing of Economic Prosperity of the British Empire. 
his firm's interest in the new book. Estimating the manuscript's length between eighty and one hundred thousand words with some twenty illustrations, Leacock forged ahead. He engaged a stenographer to keep up with his prolific output, and he had a colleague, John Culliton, a former graduate student, to take care of the book's complicated use of statistics. ${ }^{29}$ So optimistic was his mood that he had I, 900 circulars printed at Montreal which were then distributed by the Macmillan Company:

They have gone, one, to the important and larger trade and public libraries in this country, two, to the heads of banks, trust companies, loan companies, insurance offices, and so on, and three, to a hand-picked list of influential men, some members of parliament, some not, but all who are likely to be interested in the book. ${ }^{30}$

The circular announced publication in the spring of r930. Economic Prosperity in the British Empire was to be 'The Book of the Season.' Three copies of the manuscript duly arrived at the Macmillan office in Toronto on I 5 April. The Macmillan Company was entrusted to handle publication in all markets. 'There will be no difficulty whatever in our arranging terms of publication,' Leacock confidently told Eayrs. 'But what I am anxious for is that the book should have a good appearance and be put in the market with a "hurrah".,3I

Almost from the start negotiations went badly. Leacock expected an advance of $\$ 2,500$ on publication day in addition to ro percent royalty on the first 5,000 copies sold and 20 percent thereafter. Eayrs balked however at the advance Leacock suggested. In order for the Macmillans to make even a modest profit, sales would have to be in the thousands, he informed Leacock. The advance could only be possible, Eayrs stated, if publishers in America and England were willing to pay part of it. In reply, Leacock told Eayrs that the question of an advance royalty was not really important but what mattered was the publicity made by the Macmillan Company on the book's behalf. Though Eayrs was 'very keen on the book,' he realistically believed that 'the American end is [not] going to be worth a very great deal: the London end properly handled should be money making. ${ }^{32}$ Dodd, Mead \& Co. was willing to publish Economic Prosperity in the British Empire on the condition that the Macmillan Company would distribute the American edition in Canada. Wanting to publish and to maintain control of his own edition, Eayrs turned down Frank Dodd's offer. Negotiations for an American edition also fell through with Richard R. Smith Inc. and the Macmillans of New York. All three American publishers proposed to import a small number of copies of the Canadian edition. To Eayrs's astonishment and annoyance, the London branch of the Macmillans not only refused to pay an advance of $\$$ I, Ooo without seeing the manuscript, but the London branch 
declined the manuscript when it was eventually read by their editors. A saving grace was that in May, Constable's accepted the book, paying I 5 percent on the first 5,000 copies sold, 20 percent thereafter, and an export royalty of ro percent.

If negotiations had been difficult, what followed was worse. 'I have been greatly disappointed to learn that your edition of my book is still not out,' Leacock complained. He went on to say that as far as he had been kept informed, nothing had been done about an American edition; the book had already been published by Constable's and was receiving wonderful publicity in the English newspapers. It was an uncharacteristic letter of Leacock which ended 'What steps have you taken?'33 In his reply Eayrs expressed surprise at the tone of Leacock's letter. In the month of July, Eayrs had been in England expediting the publication of the English edition by arranging for the printing, notices in the press, and distribution of circulars. Leacock had previously agreed that printing the book in England would be cheaper than having the printing done in North America. He had been notified of Eayrs's cable, 'Shipping Leacock Folded Collated Sewn This Week.' ${ }^{34}$ The later publication of the Canadian edition, Eayrs explained, was due to the simple reason that the sheets bought from Constable's had to cross the Atlantic in order to be bound and sold in Canada. Economic Prosperity in the British Empire 'is our big book for Fall' I930, he told Leacock, 'and if it does not go across it will not be for want of trying. ${ }^{35}$

The Canadian edition was published a few days later on I4 August. ${ }^{36}$ The book intially sold for $\$ 2.00$ and was reduced to \$ 1.25 on 17 November I93 I. When demand stopped at the end of I933, I45 remaindered copies 'were sold as part of a lot to Simpsons at twenty cents or even less.' ${ }^{37}$ At the end of January I934, 2,07 I copies had been printed, earning Leacock approximately $\$ 220$ in royalties. On the surface, sales of the English edition appeared to be better. The book was originally listed at seven shillings and sixpence and was reduced to three shillings and sixpence on 4 February I932. On I 2 January I93 I Leacock received a cheque for $\$ 520.20$, reporting royalty on 3,890 copies; a further 78 copies were sold to 30 June I 93 I with a royalty of $\$ \mathrm{I} 8.63$. But there was a miscalculation in these figures. The Orillia Board of Trade considered the book important enough to send copies to England; members of Parliament and one hundred editors were among the persons selected to receive a complimentary copy. Indeed it irked Eayrs that the copies sent to England were from the Constable edition. He subsequently discovered that there was to be no royalty paid on these copies and that, as a result, Leacock had received an overpayment of \$255.28. Needless to say, Leacock was quite vexed when he was asked by Eayrs to return the overpayment on I6 May I93I, and he even sought legal advice on the matter. ${ }^{38}$ In short, Leacock earned approximately $\$ 500$ in total royalties on 
his book. Although this was not a complete failure, it was hardly a success, and if anything, the book's reception reflected that 'the book business [had] struck a bad patch. ${ }^{39}$ With the coming of the Depression, the days of large royalties were practically gone, even for Leacock.

When Leacock reported on the excellent progress he was making in writing Economic Prosperity in the British Empire, his relationship with the Macmillan Company was at its brightest. He had plans in store for the future sales of his books in Canada, and he fully intended to maintain his loyalty to the Macmillans. Although Gundy no longer represented Leacock, the rights in the Gundy editions were ultimately owned by Oxford University Press. Leacock wanted to regain the rights in the Gundy editions and to transfer them to the Macmillans, giving the Company exclusive rights to forthcoming titles as well. In explaining the situation to Eayrs, he related that McClelland and Stewart had already approached him about a new edition of Sunshine Sketches:

I propose to get control in Canada of all my books past and present (i.e. take them away from Oxford press to whom my lawyers are writing/ so that if ever the time comes we can get out a complete edition.... But meanwhile McClelland and Stewart want to get out a Canadian edition of Sunshine Sketches. I told them that I wanted the copyright of all my books to remain with your house and me, but that if they cared to get out an edition without holding an exclusive agency, of course, I'd be very pleased subject always to the fact that you might not think it in your interest.... I said that I would leave it entirely to you: it is too small a matter to bother with....

Don't you think that when Gundy lets go of all my books we might think about a cheap Canadian edition of the whole lot of them, - or of the best titles first? 40

In his reply Eayrs informed Leacock that since he was travelling to Montreal in the next few days, they could meet then and discuss the details of Leacock's proposal.

Although no record was kept of their discussion at Montreal in December I929, one can conjecture that Eayrs was especially pleased that Leacock intended to give the Macmillan Company sole agency in regard to the publication and distribution of his books in Canada. No contract ensued from their discussion, but undoubtedly there was a mutual understanding and commitment. A few months later when Leacock's American and English publishers each published a different anthology of Leacock's older pieces of humour, there was a disagreement between the two publishers whether the English anthology The Leacock Book would be debarred from being sold in Canada. 'The Canadian editions you have always kept in your own hands,' B.W. Willett, one of the Directors of John Lane The Bodley Head, pointed out to Leacock. 'So it is for you to say whether we are at liberty to offer an edition of The Leacock Book to a Canadian publisher and, 
if so, whether we should pay the royalty direct or whether we should arrange for the Canadian publisher to pay it to you. ${ }^{4 I}$ The issue was resolved by having the book distributed in Canada by the Macmillan Company.

In the meantime, of course, the Company was having a difficult time with negotiations over Economic Prosperity in the British Empire. The news that the other Macmillan branches had declined the manuscript must have been embarrassing for Eayrs and no doubt made Leacock wonder about the extent of cooperation among the branches. At the end of 1930, at the instigation of Leacock's English publisher, the question of Leacock's representation in Canada resurfaced. Cheap editions of some of Leacock's popular titles were going to be published by John Lane The Bodley Head. Allen Lane persuaded Leacock that sheets could be imported for the Canadian editions, that copies of the books in Canada could sell for \$ I each with Leacock earning ro percent royalty, and that the Canadian publisher would buy 3,00o copies outright among the titles to be published. The last clause implied that Leacock would receive $\$ 300$ (payment of which he requested on I July I93 I) in addition to the ro percent royalty on other copies sold. This was the deal Leacock offered to Eayrs for the Canadian agency of his books. 'If this will suit your Company it will suit me,' Leacock concluded, 'and I will close it at that. ${ }^{12}$

When one considers what was at stake financially in the long run for the Macmillan Company, it would be plausible to suppose that Eayrs immediately accepted Leacock's proposal. Oddly enough, Eayrs turned down the offer. He had talked with Allen Lane, and it was after their conversation that Lane had approached Leacock. Not only was Eayrs willing to buy sheets of the cheap English editions, he was quite eager to do so. '... We shall go after the whole series with a bang, ' he declared in agreeing to the $\$$ I list price and Leacock's ro percent royalty. ${ }^{43}$ A minor problem, Eayrs envisaged, was that McClelland and Stewart would work out a separate deal with Lane and attempt thereby to distribute copies of the English editions in Canada. '... I want the bars put up tight to McClelland importing, and if that can't be done, much as I want to go into this deal with Lane, it is off. I imagine, however, that you are in a position to see that it is done. ${ }^{44}$ The major obstacle involved a matter of principle. Eayrs simply refused to pay the advance of $\$ 300$ believing that Leacock's older works should pay their own way. In retrospect, the continuing sales of Leacock's books would prove Eayrs's belief to be erroneous. Only 'a few paltry hundred dollars' divided the two men, but there was to be no compromise on the issue. Business took precedence over friendship. Although he told Leacock that there were 'no bones broken at all,' Eayrs could not conceal his disappointment and he interpreted their failure to agree on terms as a lack of faith on Leacock's part in the Macmillan Company: 
You had in our House here a publisher at once honest and agressive[sic], a publisher who gives a good deal of himself, far more than ordinary business arrangements demand, to prosecuting the sale of his authors' books for every penny they are worth.... There are two Stephen Leacock's to me, one, the author and the other a man older than myself who is a very cherished friend. Both still remain. ${ }^{45}$

Macmillans' loss of the Canadian agency of Leacock's books did not put an end to the relationship, although the correspondence after that point is admittedly anticlimactic. The implications of the loss were perhaps not fully understood by Eayrs at the time. Thereafter Leacock dealt with several Canadian publishers. Sunshine Sketches, for example, was published by McClelland and Stewart in I93I. In I932 there was a fiasco with the Graphic Publishers of Ottawa; Leacock never earned a cent for his work on the edition of Lahontan's Voyages when the Ottawa firm went bankrupt. With the exception of Afternoons in Utopia (1932), the Macmillans ceased to be the Canadian distributor or publisher of books which originated with Leacock's American and English publishers. Only after several months of negotiation did John Lane The Bodley Head allow the Macmillans to buy sheets for a Canadian edition of Afternoons in Utopia. Listed at \$ 1.75, Leacock received a royalty of $25 \mathrm{c}$ a copy; unfortunately no publishing information about the Canadian edition is available in the Leacock-Macmillan correspondence. When John Lane The Bodley Head initially refused to let the Macmillan Company distribute or import sheets of the book, Eayrs reacted in the following way:

I am very disappointed we can't have 'Utopia'. I think, not only in our interests, but also in yours, that you are better if you can have all your new titles in the same publisher's hands. The trade is confused when the term 'A New Leacock' is used, as to whether it is Macmillan or McClelland. Beyond that, of course, I am frank to say I like to think of myself as doing all your books. However, the arrangements have been made and that's that, and no bones broken. ${ }^{46}$

In November I93 I Leacock approached Eayrs with the luca _. Inother book, a successor to Economic Prosperity in the British Empire. He had received adulatory letters from a number of distinguished people, and it was not yet apparent to him that Economic Prosperity in the British Empire was selling poorly. The Imperial Economic Conference was meeting in Ottawa late in the summer of 1932 . Leacock saw it as an opportunity to present the case once more for reduced trade barriers within the Empire, hoping thereby to influence political opinion. He had 'recently been writing a lot of stuff (syndicated) on current economics affecting the empire.... ${ }^{47} \mathrm{His}$ plan was to re-circulate this material into a coherent form. Enthusiastic as ever, he told Eayrs that a completed manuscript between 15,000 and 20,000 words could be ready in three weeks notice. True to his word, he announced on 8 


\section{MCGIL UNVarestr}

montrexal

\section{$\operatorname{hon} 21$ 1931}

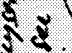

Near Jugh

II: if Constable's lekerwam frist nate.

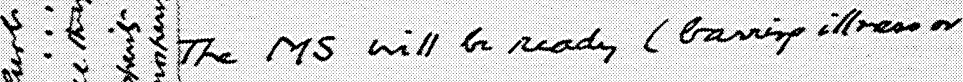

: I Laccicent) \& ace/s.

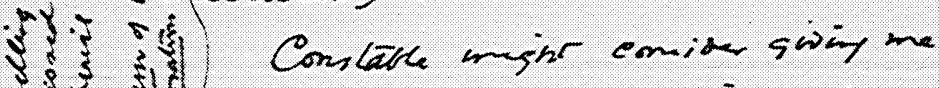

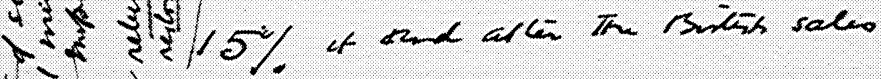

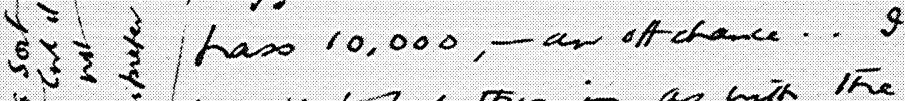

$\forall$ (i)

- Sumfine Bork hatg toy ol-. So IFes

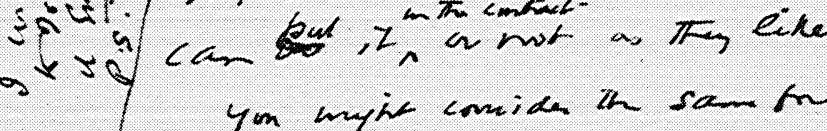

? it is oftiond as 9 trostratar it.

$\checkmark$ enclose the titite. Ion can safely fo ahead with sour sales frorgum. I

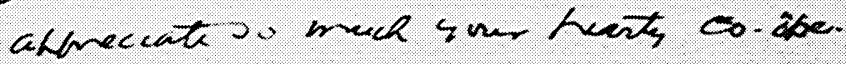

Htayn talim. Gatingas

macnater o

Suthen Kcacuch

Leacock's letter to Hugh Eayrs, 2 I Nov. I93 I. Leacock expresses his delight at Constable's decision to publish the English edition of Back to Prosperity, suggests terms of publication, and tells Eayrs to proceed with appropriate publicity. 
December: 'Book all done but am filling in some awkward figures. ${ }^{48} \mathrm{~A}$ few days later three copies of the manuscript were typed and dispatched to the Macmillans.

The book underwent several title changes. On the flyer used for promotional purposes, the title is recorded as The Coming Imperial Conference and the Return to Prosperity. Leacock finally settled on Back to Prosperity: The Great Opportunity of the Empire Conference. 'This book is no dry treatise.... The first chapter ... runs like a sparkling river. ${ }^{49}$ Such was the glowing report on the front page of The Toronto Daily Star in a review article arranged by Eayrs two weeks before the Canadian edition appeared. Eayrs was instructed to handle all markets and to issue advance publicity in the press. Although the number of copies that were sold of the Canadian edition (2,0I4) $)^{50}$ was slightly less than that of Economic Prosperity in the British Empire, Leacock actually made more money from Back to Prosperity because he had insisted on an advance royalty. It had taken him far less time and effort to write Back to Prosperity mainly because the finished manuscript was a quarter the number of words of its predecessor. Negotiations went fairly smoothly. With respect to the Canadian edition published on 8 or 9 January I932, Leacock accepted a Io percent royalty (I 5 percent after Io,ooo copies/ with an advance of $\$ 300$. The same percentage applied to the English edition with an advance of $£ 50$; the only snag was that publication by Constable's was delayed until 2 I March which upset Leacock considerably in view of the approaching meeting of the Imperial Economic Conference. The New York branch of the Macmillans decided to publish an American edition paying Leacock a $\mathrm{I} 2 \mathrm{I} / 2$ percent royalty with an advance of $\$$ Ioo. Published on 8 February, the American edition was printed from offset plates using photographs which were taken of corrected sheets of the Canadian edition - a rather innovative procedure at the time which avoided problems of proofreading. ${ }^{5 \mathrm{I}}$

The Macmillan Company of Canada published two other items written by Leacock. These were pamphlets which reflected his conservative outlook in economic theory and addressed the problems caused by the hardships of the Depression. 'Why don't you do a brief book on "Inflation"[?]' Eayrs asked Leacock at the beginning of 1933 when he had learned from George Drew that Leacock was going to speak at the Empire Club in Toronto. 'Despite Bennett's doggone stand everybody here feels that some move in this direction is bound to come,' Eayrs elaborated. 'A short book "What about inflation" - or some better title - would in my opinion do very well. ${ }^{52}$ Leacock's side of the correspondence on this subject is unfortunately not extant. The sixteen-page pamphlet that resulted sold for twenty-five cents and had the long but catchy title, Stephen Leacock's Plan To Relieve the Depression in 6 Days, To Remove It in 6 Months, To 
Eradicate It in 6 Years. His plan was to reduce the standard amount of gold in the dollar from twenty-three to seventeen grains. This would cause a rise in prices and would allow the government to issue more paper money to circulate. Confidence in the market would be restored and business would boom. 'This is not inflation,' he argued. 'It differs from it as jumping out of a balloon without a parachute differs from jumping out of a balloon with a parachute. It is the difference between letting the mainsheet out and throwing it overboard. 53

It is not clear whether Stephen Leacock's Plan was what Eayrs had in mind when he asked Leacock to write a book on inflation. Nevertheless Eayrs expressed his immediate interest, assuring Leacock: 'I don't know why you think we shouldn't care to do it just along this very line: we should. ${ }^{54}$ No publisher outside Canada was willing to put out a separate edition however. By the middle of February 1933, notices of the pamphlet's appearance had been sent out to all the major Canadian newspapers. In fact Simpsons advertised the pamphlet several days before Eayrs had even seen the manuscript. ${ }^{55}$ It was Leacock who suggested the terms to which Eayrs then agreed. No royalties were to be paid for the first 5,000 copies, but, thereafter, Leacock was to receive five cents (i.e. 20 percent) on each copy sold. Published sometime between 17 and 28 February, 200 copies of the pamphlet were distributed to leading newspapers and journals, politicans, and other interested parties. 'The book is in every store large and small where books can be sold from coast to coast, the American News Company having taken 4,000 copies on consignment,' Eayrs told Leacock. ${ }^{56}$ By I9 July I933, 4,434 copies of Stephen Leacock's Plan had been sold. The total number of copies that eventually were printed and were sold was 5,0 5.57 Strictly speaking, this would have meant that Leacock earned a sumptuous royalty of seventy-five cents.

In contrast, the second pamphlet Leacock published under the imprint of the Macmillans in Canada - his last publication with the Company earned him a respectable sum of money although the number of copies that were sold was much less than Stephen Leacock's Plan. Eayrs again took the initiative. He had seen a series of four articles which Leacock had written for the London Morning Post in July I 936. ${ }^{58}$ An outright condemnation of the Liberal government of Mackenzie King, Leacock's articles were equally critical of the waste in spending at the provincial and municipal levels. His chief example of financial mismanagement was the railway system. Canada's salvation, he concluded, can only be achieved through its vitality and its resources. Was Leacock interested in making the articles into a book, Eayrs inquired? 'I was very glad to get your telegram about publication of the Morning Post articles,' Leacock replied. ${ }^{59}$ Lovat Dickson, the former British representative of the New York branch of the Macmillans, 
had agreed to import sheets for an English edition, paying Leacock ro percent royalty up to 5,000 copies and I5 percent thereafter. ${ }^{60} \mathrm{~A}$ confusion arose however about the length of the book. Hoping to price the book at one dollar, Eayrs had thought that Leacock was going to expand his articles into a book of roughly 40,000 words where the articles by themselves ran to only 8,200 words. A compromise Eayrs suggested was that Leacock should aim at a book of 25,000 words. But Leacock was adamant that the whole merit of the Morning Post articles was 'the power of presenting much in little. A new book of 25,000 words would be an entirely different thing, less readable, less saleable and would need several months work, during which the market would be gone.... Why not publish as a pamphlet? ${ }^{6 \mathrm{I}}$

The pamphlet was titled The Gathering Financial Crisis in Canada, A Survey of the Present Critical Situation. It sold for fifty cents and Leacock received a royalty of five cents on each copy sold. He sent corrected galley proofs back to St. Martin's House on I9 September I936. The Canadian edition appeared on 8 October, and on I 3 October Leacock wrote to Eayrs saying how delighted he was with the pamphlet's appearance. 'Our travelling salesmen are all on the road at the moment, and [are] equipped with copies of [the] booklet,' Leacock was informed. ${ }^{62}$ Book dealers, the trade newspapers, and even the railways had been contacted. It was definitely not a best seller however. In all, it would appear that I,470 copies of The Gathering Financial Crisis were printed and sold; half ( 735 copies) were published for the English edition and half for the Canadian. ${ }^{63}$

Leacock's participation in the McGill series and the publication of his own books by the Macmillans in Canada do not tell the entire story of his relationship with the Company. He contributed prefaces to a number of Macmillan books, and many of his earlier writings were reprinted in Macmillan anthologies. ${ }^{64}$ His opinion of books published by the Company was often solicited for publicity purposes. There were also projects proposed which were either rejected, left unfinished, or transformed into another work. In particular three ventures of this kind stand out and merit discussion.

The first of these occurred shortly after the publication of Back to Prosperity. Leacock had just written an article for the New York Herald Tribune Magazine in which he advocated that European war debts with the United States could be cancelled if ownership and sovereignty of the Congo basin were transferred to the United States. He actually argued that the influx of American capital, brains, and labour - American blacks would be returned to their homeland - would bring stability to the African continent. ${ }^{65} \mathrm{He}$ wired Eayrs, who happened to be in New York City at the time, suggesting that his ideas on the subject could be expanded into a small book to sell for one dollar. Eayrs conferred with his colleagues at the New York branch who 
advised against going ahead, ostensibly for two reasons: sales of the proposed Congo book would compete with and hurt sales of Back to Prosperity; the subject of war debts was considered too thin by itself to interest readers sufficiently. Having received a lukewarm response, Leacock decided 'to let the Congo book go for the present. ${ }^{, 66}$

Plans for the other two projects were more substantial in nature. In September 1934 Leacock sent Eayrs a clipping from the New York Times Magazine, a feature article he had written on the occasion of the four hundredth anniversary of the landing of Jacques Cartier in Canada. ${ }^{67}$

Please read it, not for pleasure but as a business duty. You will observe (I hope) the wonderful condensation and picturesqueness and the way in which the economic basis of our history is revealed (... If you don't, you're a nut)....

This will give you the ground plan to my Economic History of Canada, for schools and colleges. I propose to write it this winter to be ready (published) in time for the school session of $1935-36 .^{68}$

He submitted an outline for Eayrs's consideration and suggested terms for publication. What he envisaged was a book of 125,000 words /four hundred pages), Io percent royalty on the first 5,000 copies sold, I 5 percent on 5,000 to 15,000 copies, and 25 percent thereafter. He also wanted a guaranteed royalty of $\$ 400$, to be paid three months after publication, to cover the cost of 'library assistance and stenographic and clerical work.... I spent so much money on my Economic Integration of the British Empire [i.e. Economic Prosperity in the British Empire] that I made nothing out of it. ${ }^{69}$

Leacock's proposal in September 1934 to write Economic History of Canada was not the first time he had mentioned the subject to Eayrs. 'Yes, I have in mind the Economic History,' Eayrs assured Leacock the previous January. 'Toward the end of this month or early in February I shall be in Montreal and perhaps we can get some time and discuss it fully together. ${ }^{170}$ In October Leacock told Eayrs that he was 'starting out the ground,' and he projected I 5 January I 936 as a publication date. ${ }^{7 \mathrm{I}}$ 'I am very keen about this book,' Eayrs replied. '... The more I talk about it and the more I talk it over with our Educational men, the more I think we have a winner. ${ }^{172}$ The title was even copyrighted. But there is nothing further in the extant correspondence about Economic History of Canada. For one reason or another, Leacock abandoned the project.

The other substantial project contemplated by Leacock was not left unfinished but rather was altered both in terms of subject matter and intended audience. Moreover, when the book was eventually published it did not appear in a Canadian edition. On the provisional draft of the table of contents of December 1938, the title is recorded as The Economics of the British Empire, A Book for Schools and Colleges. The subtitle indicates 
that the book was 'designed to meet the definite needs of school and college classes rather than for the casual perusal of the general reader. ${ }^{173}$ An internal Macmillan memo addressed to Eayrs reported that there were no university courses on such a subject and none in the secondary schools; if simply written, Leacock's book could perhaps be used as a reference text. ${ }^{74}$ Eayrs conveyed this information to Leacock, while remaining supportive nevertheless:

Your writing it would be a return to your early love, for that first book [Elements of Political Science] of yours, I take it, still goes on.... Therefore we are definitely interested, and if you are going ahead and can give us some idea of time schedule no doubt you will do so. ${ }^{75}$

Again there are no further letters known to be extant between Leacock and Eayrs about this project. Published in 1940 by Dodd, Mead \& Co. and by John Lane The Bodley Head, the American title was The British Empire: Its Structure, Its Unity, Its Strength, the British title Our British Empire: Its Structure, Its History, Its Strength. The book was not designed specifically for students. Although a principal aspect of the book was economic, the book had a much broader focus than that outlined in the provisional draft. It is not readily apparent why the Macmillan Company did not publish its own edition. The termination of Leacock's relationship with the Company upon the death of Eayrs in I 940 may have been the major reason.

There is no surviving correspondence for 1939, and only one letter is extant for 1940. Written by Eayrs toward the end of January, the letter begins 'It is good to see your firm handwriting again' and concludes 'How are you and how is Steve the younger [Leacock's son]? - both I hope flourishing. My affectionate regards as always. ${ }^{176}$ The main part of the letter refers to 'your piece on Georgina' which Eayrs was planning to send to several Canadian newspapers for publication. By way of recompense, Leacock received a cheque for twenty-five dollars from the Macmillan Company. Not listed in any of the Leacock bibliographies, the piece is a short appreciative review of Francis Paget Hett's Georgina, A Type Study of Early Settlement and Church Building in Upper Canada published by the Macmillans in Toronto in I939. '"Georgina",' Leacock wrote 'narrates the story of Georgina Township on the south side of Lake Simcoe, as centered round the first building of its little wooden church, later to be replaced by the present beautiful building in stone, a memorial erected by the Sibbald family, who played such a large part in the settlement of the district. ${ }^{.77}$ In the preface, Leacock is gratefully acknowledged by the author, a descendant of the Sibbald family. There are also quotations in the book from Leacock's works and references to his family who settled in Georgina near the village of Sutton in I876. Leacock's reminiscences of living on a farm in Georgina are 
chronicled in the second chapter of his unfinished autobiography; in accordance with his own wishes, his ashes were buried in the churchyard of St. George's Church at Sibbald's Point. ${ }^{78}$

Whether Leacock replied to Eayrs's last letter is not known. Three months later on 29 April 1940, Eayrs died of a heart attack at the age of forty-six. Charming, gregarious, but unpredictable, he had pursued publishing as an adventure with little regard to his deteriorating health. The Macmillan Company's relationship with Leacock was wholly dependent on the personal interaction between Leacock and Eayrs. In effect the death of Eayrs put an end to the relationship and marked the last hope the Company might ever have had of becoming Leacock's sole Canadian publisher.

NOTES

I The archival material relevant to this article is located at two repositories: the Macmillan Company of Canada Archive (hereafter Mc) at Mills Memorial Library, McMaster University, Hamilton, Ont. and the Leacock papers at the Stephen Leacock Memorial Home (hereafter sL), Orillia, Ont. Quotations from Leacock's unpublished writings are made with the permission of Leacock's niece, Mrs. Barbara Nimmo. I am indebted to my colleague, Bruce Whiteman, for his encouragement, advice, and assistance. The letter quoted is from MC.

2 Eayrs to Leacock, Io Feb. I926 (MC).

3 Wise to Sir Frederick Macmillan, 30 Oct. I908 (Mc). See also Brett to Wise, r 3 Oct. I 908 (MC), and Sir Frederick Macmillan to Wise, I9 Oct. I908 (MC).

4 Wise to the Publisher Association Ltd., 30 Aug. I9 2 (MC). By this date, Leacock had been contracted to write two books for the Morang series: Jacques Cartier and The Dawn of Canadian History. The former was already in galleys when Wise sold the series to Glasgow, Brook \& Co. The name of the series was changed to Chronicles of Canada, and Leacock wrote three of the thirty-two volumes: vol. I, The Dawn of Canadian History, A Chronicle of Aboriginal Canada (1914); vol. 2, The Mariner of St. Malo, A Chronicle of the Voyages of Jacques Cartier (1914); and vol. 20, Adventures of the Far North, A Chronicle of the Arctic Seas (I9I4).

5 Wise to Brett, 22 Nov. I920 (MC).

6 Ralph L. Curry, Stephen Leacock: Humorist and Humanist (Garden City, New York: Doubleday \& Co., I959), p. I88. Although Curry provides some publishing information on Leacock's relationship with his American and English publishers, there is little in his biography on Leacock's interaction with his Canadian publishers.

7 Bruce Whiteman, 'A Canadian Publishing House: Some Notes on the Macmillan Company of Canada Archive at McMaster University Library, Hamilton, Canada,' Publishing History ro (I98I): 56-60; Eayrs, 'Renaissance in Canadian Life,' Canadian Bookman, n.s. 4, no. ro (Oct. I922): 263; Eayrs, 'Publishers Are Getting over the Fear That Putting out a Canadian Book is Taking a Chance-Big Change Is Noticeable,' Bookseller and Stationer 38 (Oct. I922): 27; [Eayrs], A Canadian Publishing House (Toronto: The Macmillan Company of Canada, I923), p. I9. For biographical information on Eayrs, see John Morgan Gray, Fun Tomorrow, Learning to Be a Publisher and Much Else (Toronto: Macmillan of Canada, I978), pp. I35-9, I $87-9,232-43$. 
8 Eayrs to Leacock, 8 June r93 I (SL).

9 Curry, Stephen Leacock, p. I85.

Io Royalty statement, I May I930(sL).

II Eayrs to Leacock, 8 June I93 I (SL).

I2 The proposed agreement is in MC. Although the agreement is dated I926, the publishing information in the first four monographs indicates that they were published in 1925 . There is also a formal memorandum of agreement dated I May 1928 (MC).

I3 Eayrs to Leacock, 3 I Aug. I926 (MC).

I4 The prefaces were written for the following monographs: no. I, L.M. Fair, The Transportation of Canadian Wheat to the Sea (I925); nos. 2 and 4, the 1925 Graduating Class in Commerce, Ocean and Inland Water Transport (I925) and Reciprocal and Preferential Tariffs (1925); no. 6, Laurence Chalmers Tombs, The Port of Montreal (1926); no. 9, John Thomas Culliton, Assisted Emigration and Land Settlement with Special Reference to Western Canada (1927); and no. I4, M.M. Mendels, The Asbestos Industry of Canada (I930). Although no. 9 was sold and distributed by the Macmillan Company of Canada, it was published by the Federated Press, Ltd., Montreal. The Macmillan Company ceased publication of the series after no. I 3. Nos. I, 2, and I4 are missing from $A$ Bibliography of Stephen Butler Leacock and Gerhard R. Lomer's Stephen Leacock: A Check-List and Index to His Writings; they are recorded in Ralph L. Curry's 'Stephen Butler Leacock: A Check-List,' Bulletin of Bibliography 22 (Jan.-Apr. I958): 106-9. Leacock also wrote a preface to Philip F. Vineberg's thesis, The French Franc and the Gold Standard 1926-36 (Montreal: Printed at the Witness Press, [1936]). Although it was not one of the monographs of the McGill series, Vineberg's thesis appeared as 'one of the series of Guy Drummond Publications issued under the auspices of the Department of Economics and Political Science at McGill University.' In his preface dated Aug. I936, Leacock remarked that he 'was very proud to think that the last of such monographs prepared under my direction at McGill should be such an excellent piece of work.' See Vineberg, 'Collapse of the French Franc' in Allan Anderson, Remembering Leacock, An Oral History (Ottawa: Deneau, I983), pp. 176-7.

I5 Leacock to W.H. Clarke, ca. Nov. I929 (MC).

I6 Leacock to Goforth, 9 Sept. I926 (MC). When he was asked what role Leacock played in getting his thesis published, Eugene Forsey commented: 'I left for Oxford before the thing was undertaken. A colleague (whom I later discovered to be a drunkard) handled it with appalling results as to proof-reading. Macmillans did a lot of these theses.' Hon. E.A. Forsey to Carl Spadoni, Jan. I984.

17 Leacock to T.H. Harris, 16 Nov. 1929 (MC).

I8 Macmillan Company internal memo, I929 (MC).

I9 Many of the letters to libraries, universities, and corporations were sent by the Macmillan Company on Leacock's behalf. The letters were typed on his department notepaper, and his signature was forged by a Macmillan representative. See Eayrs's memo to John Irwin, 2 I March 1929 (MC).

20 Leacock to W.H. Clarke, 2 June I 929 (MC).

2I Eayrs to Leacock, 5 June I 929 (MC).

22 Eayrs to Leacock, 2I Nov. I929, 4 Dec. I 929 (MC).

23 Macmillan Company to Leacock, 22 March 1932 (MC).

24 The Macmillan Company supplied Leacock with a list of series' subscribers and advised him on Canadian bookstores that would sell the series in their stores. No. 
I4 was mailed to subscribers by the Macmillan Company, but it would appear that Leacock took care of the series thereafter. See the Macmillan Company to Leacock, 9 Oct. I930 and 27 March 193 I (SL).

25 Leacock to Eayrs, 22 Nov. I929 (MC).

26 Leacock had signed a contract for this book with the American branch of the Macmillans. When he asked Eayrs whether the New York office would renew the contract, Eayrs replied that the contract did not need to be renewed since it had never been cancelled. The book was never published however. Part of the manuscript is extant at the McLennan Library, McGill University, Montreal. See Eayrs to Leacock, Io Jan. I93 I (sL).

27 Leacock to Eayrs, 22 Nov. I 929 (MC).

28 The British Empire: Its Structure, Its Unity, Its Strength (New York: Dodd, Mead \& Co., r940), p. vi.

29 Leacock to Eayrs, 5 Dec. I929, 24 Jan. I930 (MC).

30 Eayrs to Leacock, I2 April 1930 (MC).

3 I Leacock to Eayrs, 5 Dec. I 929 (MC).

32 Eayrs to Leacock, I4 Feb. I930(SL).

33 Leacock to Eayrs, 9 Aug. 1930 (MC).

34 The Macmillan Company to Leacock, 8 July I930 (MC).

35 Eayrs to Leacock, I2 Aug. I930/(sL).

36 The production card for the book in Mc has the date of publication as I 2 Aug. 1930, but Eayrs's letter to Leacock on that date has the sentence: 'The Canadian edition will be finished binding and issued on Thursday [I4 Aug. I930].'

37 Eayrs to Leacock, 3I Jan. I936 (SL).

38 Leacock also sought legal advice on Constable's delay in publishing his book Back to Prosperity. He realized that Eayrs had made an honest mistake in calculating the royalties from Constable's. Nonetheless Eayrs wrote: 'There is no fuss between you and me: I should dislike it even more than you.... What the devil two friends want to refer a matter of this kind to an attorney, despite the excellence of that attorney, for, I don't know.' See Eayrs to Leacock, I7 March I932 (SL).

39 Eayrs to Leacock, Io Jan I93 I (SL).

40 Leacock to Eayrs, 5 Dec. I 929 (MC).

4I Willett to Leacock, Io April I930 (MC).

42 Leacock to Eayrs, I6 Dec. I930 (MC).

43 Eayrs to Leacock, I8 Dec. I930 (MC).

44 Ibid.

45 Eayrs to Leacock, Io Jan. I93 I (SL).

46 Eayrs to Leacock, 9 Feb. I932 (SL). One review of Afternoons in Utopia that especially bothered Leacock was an unsigned notice of four lines in the London Advertiser, Io Dec. 1932, p. 4. The reviewer, who turned out to be none other than William Arthur Deacon, claimed that Leacock's humour 'is now as standardized a product as a comic strip, and just about as subtle and witty.' Eayrs wrote to Leacock, 2 Feb. I 933 (sL): 'Of course, here in Toronto we're so sick by now of Deacon's lapses from taste every now and then, we take no more notice of him. He appears to have two vendettas, one against Englishmen and all other things English, and the other against men of academic standing, - why, God only knows.' Deacon was the first Chairman of the Award Committee of the Leacock Medal of Humour. Cf. Clara Thomas and John Lennox, William Arthur Deacon: A Canadian Literary Life (Toronto, Buffalo and London: University of Toronto Press, I982), pp. I89, 227-8. 47 Leacock to Eayrs, [n.d. ca. Nov. I93 I], (MC). 
48 Leacock to Eayrs, 8 Dec. I93 I (MC).

49 Frederick Griffin, "Thomas Hit Nail on Head When He Cried "Humbug", Stephen Leacock Says 25,000,000 Unemployed Could Stage a War with Benefit, Cancel War Debts,' The Toronto Daily Star, 2 I Dec. I93 I, pp. I-2. The Macmillan Company of Canada published two books Griffin wrote, Soviet Scene (1933) and Variety Show (I935). Griffin was 'a feature writer for the Toronto Star Weekly and about the bestknown newspaperman in Canada.' Both he and Eayrs were members of the Toronto Writers' Club. See Wilfrid Eggleston, Literary Friends (Ottawa: Borealis Press, I980), pp. 24-5. Leacock himself heralded the appearance of Back to Prosperity by writing 'Beating Back to Prosperity,' The Mail and Empire, 28 Nov. I93 I, p. 3; also in Imperial Oil Review I 5 (Dec. I93 I): 2-4.

50 From the production card of Back to Prosperity (MC).

5I Publishing information concerning the editions of Back to Prosperity was obtained from the following letters and sources: Eayrs to Leacock, 24 Nov. I93 I (SL), 28 Dec. I93 I (SL), 5 Jan. I932 (SL), and I 8 Feb. I932 (SL); the Macmillan Company to Leacock, 9 Jan. I932 (MC) and I7 Feb. I93 I (MC); Macmillan contract with Constable's, 3 I Dec. I93 I (MC).

52 Eayrs to Leacock, 30 Jan. 1932 (SL).

53 Stephen Leacock's Plan, pp. 7-8.

54 Eayrs to Leacock, 2 Feb. 1933 (sL).

55 Eayrs to Leacock, I7 Feb. I933 (SL). See The Globe, I7 Feb. 1933, p. 8.

56 Eayrs to Leacock, 6 March 1933 (sL).

57 Eayrs to Leacock, I9 July I933 (SL); see also the production card for Stephen Leacock's Plan (MC).

58 The articles were reprinted under the general heading, 'Our Gathering Financial Crisis,' in three instalments of the Toronto Financial Post; Leacock received fifty dollars payment, twenty dollars of which he payed to Eayrs. See The Financial Post, 26 Sept. 1936, p. 3; 3 Oct. 1936, p. 3; and ro Oct. I936, p. 3. On Leacock's relationship with the editor of The Financial Post, see Floyd S. Chalmers, Both Sides of the Street, One Man's Life in Business and the Arts in Canada (Toronto: Macmillan of Canada, A Division of Gage Publishing Ltd., I 983), pp. 7, I3, I6, I9, 56-7.

59 Leacock to Eayrs, Io Aug. 1936 (MC).

60 Contract with Lovat Dickson Ltd., ca. Aug. I $936(\mathrm{MC})$. It is interesting to note that clause twenty of the contract stated 'It is hereby agreed that the publishers shall have the first opportunity to consider for publication the next two books by the same author.'

6I Leacock to Eayrs, 25 Aug. I936 (MC).

62 Eayrs's secretary (Ellen Elliot) to Leacock, I4 Oct. I936 (MC).

63 Macmillan production card for The Gathering Financial Crisis (MC).

64 See, for example, the following: 'The Great Election in Missinaba County' in Canadian Stories (1928), ed. Raymond Knister, pp. 87-I I 8; preface to Henry Laureys, The Foreign Trade of Canada (r 929), pp. vii-ix; 'Soaked in Seaweed or Upset in the Ocean' in The Canada Book of Prose and Verse, Book Five /with The Ryerson Press, I935), eds. C.L. Bennet and Lorne Pierce, pp. 467-71; 'John Cabot' in Argosy to Adventure (with The Ryerson Press, I935), eds. Bennet and Pierce, pp. 9I 2; 'The Sinking of the "Mariposa Belle" ' in Prose for Senior Students, An Anthology of Short Stories and Essays (I95 I), eds. J.L. Gill and L.H. Newell, pp. I 526.

65 'Colonies for War Debts?' in the New York Herald Tribune Magazine, Section xII of 
the New York Herald Tribune, I7 Jan. 1932, pp. I-2.

66 Eayrs to Leacock, I Feb. 1932 (sL).

67 'Stirring Pageant of Canadian History,' The New York Times Magazine, ig Aug. I934, pp. 6-7, I7.

68 Leacock to Eayrs, I7 Sept. I934 (MC). It is interesting to note that a book with the identical title was advertised as forthcoming in the Macmillan catalogues for 1928 9. Authored by S. Hayes, it was described as a two-volume work, with an introduction to volume one by Leacock. The Macmillan catalogues do not list the book as actually published however, and no listing of it has been verified in any bibliography or collection.

69 Ibid.

70 Eayrs to Leacock, I7 Jan. I934 (sL).

7 I Leacock to Eayrs, 9 Oct. I 934 (MC).

72 Eayrs to Leacock, I2 Oct. I934 (MC).

73 Draft of The Economics of the British Empire, Dec. I938 (Mc).

74 Frank A. Upiohn to Eayrs, 7 Dec. 1938 (MC).

75 Eayrs to Leacock, I2 Dec. I938 (MC).

76 Eayrs to Leacock, 26 Jan. I940 (SL).

77 'The Fly Leaf,' The Globe and Mail, io Feb. I940, p. I I. 'The Fly Leaf' was the name of William Arthur Deacon's column. Eayrs sent Deacon a copy of Leacock's review on 5 Feb. I $940(\mathrm{MC})$. The review also appeared as: 'Of Georgina Township and Its First Church,' The Gazette (Montreal), ro Feb. 1940, p. 5; 'Country Chronicle Recaptures Past,' Winnipeg Free Press, 9 March I940, p. I 3. The review was submitted to The Daily Province of Vancouver, but it was not located in searching the newspaper to the end of May I940.

78 See 'Life on the Old Farm' of 'Some Chapters of Autobiography' in The Boy I Left Behind Me (London: The Bodley Head, 1947), pp. 37-68; Elizabeth Kimball, The Man in the Panama Hat: Reminiscences of My Uncle, Stephen Leacock (Toronto and Montreal: McClelland and Stewart, I970), chapter I6 'A Funeral at the Lake.'

All illustrations are courtesy of the William Ready Division of Archives and Research Collections, McMaster University. 